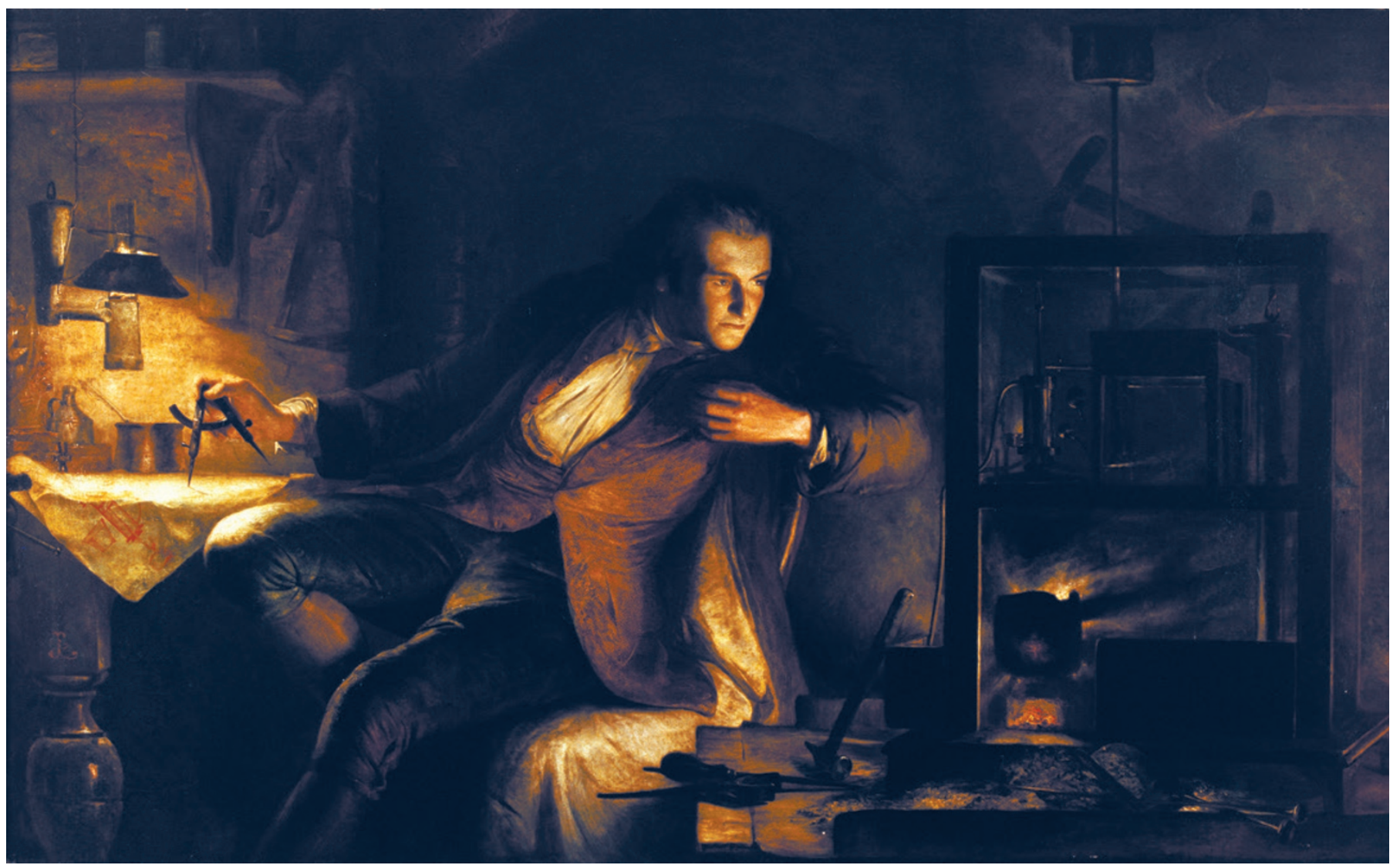

James Eckford Lauder's James Watt with the Newcomen Engine (1855), painted after the late engineer had become a celebrated figure.

\title{
HISTORY OF ENGINEERING
}

\section{Wonder maker}

\section{Andrew Robinson delves into a study inspired by James Watt's fascinating workshop.}

\section{$\mathrm{I}$}

n 1924, London's Science Museum acquired the entire workshop of engineer James Watt, left almost untouched in the attic of his house in Birmingham, UK, since his death more than a century before. The museum put a recreation of the workshop on permanent display in 2011. Among the 8,434 items left by the Scotsman, best known for his innovative steam engine, is an enormous range of tools, including the earliest known circular saws. There are also mathematical instruments, optical experiments, minerals and chemicals, pottery and ceramics made by Watt, busts of famous figures waiting to be copied in plaster of Paris, and engine-related objects - such as a box containing the fragments of his attempts to make an engine that used pure rotary motion.

This workshop inspired Ben Russell, the Science Museum's curator of mechanical engineering, to write his engaging James Watt: Making the World Anew. He explains that the volume of material, "crossing the boundaries between philosophy and craft, makes it hard to cat- James Watt: egorize the contents Making the World against any one of Anew the labels which have been applied to Watt BEN RUSSELL Reaktion: 2014. over time: philosopher or craftsman primarily, but engineer and chemist, as well." The diversity of Watt's interests and activities was astonishing, even when compared with the achievements of his Enlightenment contemporaries. Chemist, inventor and Royal Society president Humphry Davy, for instance, called him a "modern Archimedes" whose inventions had made industrialized Britain remarkably powerful for such a small nation.

Watt's first steam engine, which began operating in 1776 , was successful because it had three times the coal-combustion efficiency of the existing engine designed by Thomas Newcomen, introduced in 1712. The steam cylinder in Newcomen's 'atmospheric' engine had to be sprayed with cold water at each cycle to condense the steam, creating a partial vacuum that allowed atmospheric pressure to push the piston down. In 1765, in Glasgow, Watt had a "major leap of imagination", as Russell puts it: the idea of building a separate condenser, so that cylinder and piston did not lose heat. By patenting the principles of the condenser and not the means of applying them, Watt and his business partner Matthew Boulton became wealthy, although not without a long legal battle against their rivals in the 1790s. Their engine - its power defined in horsepower, a unit invented by Watt and today most commonly converted as 746 watts became an industry standard by 1800 , for pumping water from mines and driving machinery in mills and factories.

From 1804, Watt moved from steam to sculpture, creating plaster of Paris copies of busts, then much in demand among the wealthy. His 'sculpture machine' was a three-dimensional pantograph, powered by a treadle and worked by means of linked and geared arms, one ending in a probe 
and one in a high-speed, rotating cutting tool. As the probe traced the surface of the original bust, the tool duplicated its motion and cut a plaster block. Today, about 400 of Watt's sculptures are in storage at the Science Museum, including casts, busts, depictions of contemporaries including the chemist Joseph Black, and copies of Boulton's 1809 death mask. After his own death in 1819, Watt became the first engineer to be commemorated in Westminster Abbey. For the Victorians, Russell shows, Watt was "a new kind of industrial hero" whose stature was comparable to Isaac Newton's as a physicist.

As Russell admits, there is no shortage of recently published studies of Watt, such as

"Watt was

'anew kind

of industrial

hero' whose

stature was comparable to

Isaac Newton's as a physicist." Richard Hills's threevolume biography James Watt (Landmark, 2002-06) and James Watt, Chemist by David Miller (Pickering \& Chatto, 2009). But where Russell focuses on Watt as a man able "not just to think but to do: to use tools, techniques and materials, to create tangible things across a range of activities", most studies tend to emphasize his capacity as a thinker. Perhaps that tendency is inevitable. Scientists and science historians generally revere original theories with unforeseeable consequences more than practical inventions with immediate applications - Newton and Albert Einstein more than Christopher Wren, Watt and Thomas Edison. For all the wonderful creativity on display in his workshop, Watt was essentially earthbound. Yet his life and work are decidedly relevant to the debate about how scientific discoveries are best turned into marketable inventions. Watt's way of working - with a business partner and a patentable purpose, whether an efficient coal-driven means of pumping flood water out of mineshafts or the mass production of pottery - could hold lessons for any university or government keen to promote technology transfer.

Watt was born in Scotland, trained as an instrument maker in England, made his breakthrough with the steam engine in Scotland, and began manufacturing it in England, where he settled. Next month, there will be a referendum on Scottish independence from the United Kingdom. Whatever the outcome, Watt's remarkable life is a definite benefit arising from the close economic, intellectual and cultural union of Scotland and England.

Andrew Robinson is the author of The Last Man Who Knew Everything - a biography of the polymath Thomas Young - and editor of The Scientists.

e-mail:andrew.robinson33@virgin.net

\section{Books in brief}

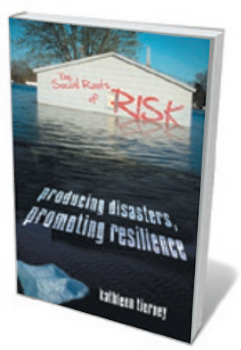

The Social Roots of Risk: Producing Disasters, Promoting Resilience

Kathleen Tierney STANFORD UNIVERSITY PRESS (2014)

The origins of disaster lie in "the ordinary everyday workings of society", avers sociologist Kathleen Tierney in this brilliant treatise. Drawing on a trove of timely case studies, Tierney analyses how factors such as speculative finance and rampant development allow natural and economic blips to tip more easily into catastrophe. Resilience, she argues, is rooted in sustainable ecological and social development. It is transformative risk reduction, not bailouts, that will help humanity to weather coming upheavals.

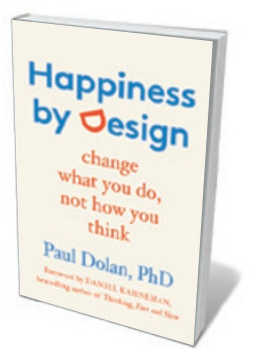

Happiness by Design: Change What You Do, Not How You Think Paul Dolan HUDSON STREET (2014)

The science of happiness has been with us since at least the 1940s, when Abraham Maslow's ideas opened up a psychology based on feeding the potential for positivity rather than simply treating symptoms. To this now-crowded table, behavioural scientist Paul Dolan brings a feast of US and European research, and some significant insights. Dolan argues that happiness depends on where we focus our attention, and on how well we balance purpose and pleasure. His action-oriented outline for achieving that equilibrium draws in part on work with eminent psychologist Daniel Kahneman.

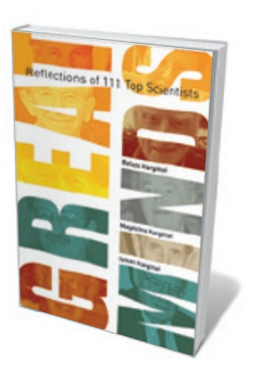

\section{Great Minds: Reflections of 111 Top Scientists}

Balazs Hargittai, Magdolna Hargittai and Istvan Hargittai

OXFORD UNIVERSITY PRESS (2014)

Over two decades, chemists Balazs, Magdolna and Istvan Hargittai interviewed hundreds of prominent scientists, including 68 Nobel laureates. This distillation features excerpts from 111 of these frank conversations. Featured are mathematician John Conway on how his discovery of surreal numbers was like finding a palace after drifting around a strange city; physicist Gerard 't Hooft on the improbability of intelligent extraterrestrials; and physicist Mildred Dresselhaus, biologist Francis Crick, and more on the fascination of the life scientific.

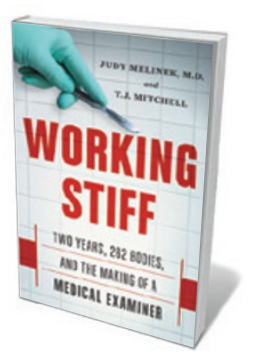

Working Stiff: Two Years, 262 Bodies, and the Making of a Medical Examiner

Judy Melinek and T. J. Mitchell SCRIBNER (2014)

"A hard hat was still there, lying on its side in a pool of blood and brains, coffee and doughnuts." Judy Melinek's inside story on forensic-pathology training, written with her husband, writer T. J. Mitchell, is inevitably big on gore. But Melinek, a "sunny optimist", offers more than cheap thrills. The flamboyant disclosures - how to handle rotting flesh or use pruning shears to snap ribs - are balanced by her soul-baring account of identifying human remains in the wake of the terrorist attacks in New York on 11 September 2001.

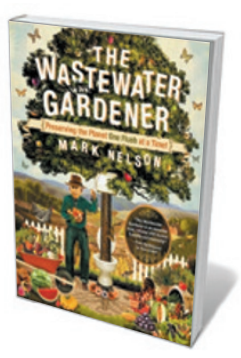

The Wastewater Gardener: Preserving the Planet One Flush at a Time

Mark Nelson SYNERGETIC (2014)

It takes 1,000 tonnes of water to move 1 tonne of human faeces, notes engineer Mark Nelson. His alternative to costly, unsustainable sanitation is constructed wetland - subsurface-flow gravel beds in which plant roots and microbial action purify wastewater for a full range of uses. Nelson, a veteran of the 1990s US survivability experiment Biosphere 2, has built "wastewater gardens" from Algeria to Australia, Mexico and beyond. Barbara Kiser 